\title{
SOUTHERN ELEPHANT SEALS (MIROUNGA LEONINA) ON THE COAST OF RIO DE JANEIRO STATE, BRAZIL
}

\author{
Fagner A. de Magalhães ${ }^{1}$, Lucas B. Hassel ${ }^{1}$, Andréa C. Venturotti ${ }^{1}$ and Salvatore Siciliano ${ }^{1}$
}

Southern elephant seals have a circumpolar breeding and moulting distribution on both sides of the Antarctic Convergence, presenting two pelagic and two terrestrial phases in their annual cycle. They come ashore to breed (August to November) and moult (December to February) spending the rest of the year at sea (King, 1983). Animals born and tagged at Punta Norte (Península Valdés, Argentina $-42^{\circ} \mathrm{S}$ ) and adjacent areas are found moulting or reproducing as far as $120 \mathrm{Km}$ from their place of birth (Campagna and Lewis, 1992), but some seals are dispersed more than $1000 \mathrm{~km}$ away from Patagonia, at Malvinas (Falkland) Islands (Lewis et al., 1996). Tarr (1987) reported a $3.4 \mathrm{~m}$ female elephant seal resident on the Skeleton Coast of South West Africa. Ross (1969) suggests that the elephant seals recorded along the Southern African coastline originate from the Prince Edward Islands $\left(46^{\circ} 50^{\prime} \mathrm{S}, 37^{\circ} 50^{\prime} \mathrm{E}\right)$ and presumes that the animals observed along the South West African coast have been carried northwards by the Benguela current.

Some unusual occurrences of southern elephant seals have been reported for the Brazilian coast. A review of records indicates occasional observations of southern elephant seals in Fernando de Noronha Island (Lodi and Siciliano, 1989), Rio de Janeiro, Santa Catarina, Paraná and Rio Grande do Sul (Castello and Pinedo, 1977; Castello, 1984; Pinedo, 1990; Pinedo et al., 1992; Simões-Lopes et al., 1995; Drehmer, 1998). Recent information on the occurrence of $M$. leonina along the Brazilian coast have been reported in Southern (Silva et al., 2000), Southeastern (Sanctis et al., 2002) and Northeastern regions (Serra et al., 2000). Two unpublished records are also known for the Rio de Janeiro State coast: a male at Praia da Moreninha, Paquetá on 15 March 1994 (complete skeleton at Museu Nacional, collection number MN 50785) and a 3.20m male at Praia de João Fernandes, Búzios on 23 June 1999. The scarcity of data on the biology of M. leonina on the coast of Brazil makes the understanding of its movements and migration patterns more complicated. The observations in this note are from Arraial do Cabo $\left(22^{\circ} 58^{\prime} \mathrm{S}, 042^{\circ} 01^{\prime} \mathrm{W}\right)$, Rio de Janeiro, Southeastern Brazil. In this area, a change in coastal direction from north-south to east-west in Cabo Frio and the proximity of the $100 \mathrm{~m}$ isobath, leads to a topography which promotes upwelling of deep cold South Atlantic Central Waters (Valentin, 2001). This note reports on two elephant seals recently observed on the beaches of Arraial do Cabo: one specimen on September and October 2001, and a second from July to November 2002. The first specimen was observed at Prainha, on the 20 September, following several sightings from 21 to 24 September 2001 and on 5 October 2001 at Praia Grande, Arraial do Cabo. It was a $2.8 \mathrm{~m}$ immature male, confirmed by extrusion of the penis. Its estimated weight was approximately $500 \mathrm{~kg}$. The second specimen was sighted at Prainha, on 29 July 2002 and on the following day at Praia Grande. It was an immature male approximately $3.4 \mathrm{~m}$ in length, $1.02 \mathrm{~m}$ wide and weighing $800 \mathrm{~kg}$ (Fig.1). It had a few barnacles attached to its left fore flipper, neck and back. Some were collected and identified as Conchoderma auritum (Lepadidae).

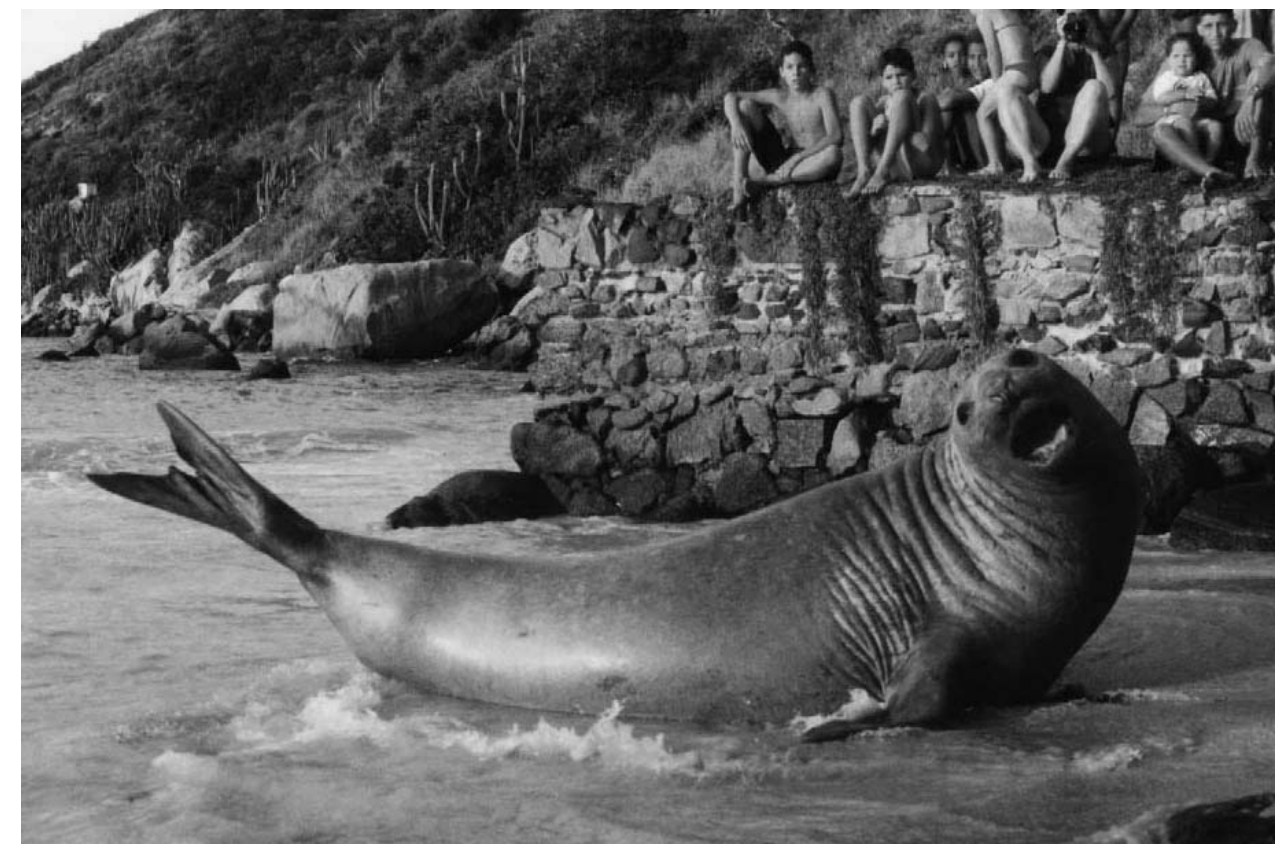

Figure 1. Immature male elephant seal observed at Prainha, Arraial do Cabo, on 29 July 2002. Photo: Lucas B. Hassel.

${ }^{1}$ Grupo de Estudos de Mamíferos Marinhos da Região dos Lagos (GEMM-Lagos), Laboratório de Ecologia, Departamento de Endemias Samuel Pessoa, Escola Nacional de Saúde Pública/FIOCRUZ. Rua Leopoldo Bulhões 1480, Manguinhos, Rio de Janeiro, RJ, 21041-210, Brazil. 
Both elephant seals showed a healthy appearance. This fact is confirmed by frequent movements from one beach to another as well as reported sightings in nearby waters as far as $25 \mathrm{~nm}$ east and northwest of Arraial do Cabo for both elephant seals. These sighting reports continued up to 31 October 2001 to the east as far as Itaúna, Saquarema, for the first elephant seal and up to November for the 2002 specimen. While on the beach, both specimens defecated a couple of times indicating recent feeding. It suggests a probable connection with these highly productive waters which provides appropriate conditions for feeding. The origin of such specimens is unknown. These occurrences seem to be the result of erratic movements of $M$. leonina and may reflect some population increase on their breeding grounds.

\section{Acknowledgements}

We would like to thank Prof. Paulo S. Young (Carcinologia - DI/Museu Nacional/UFRJ) for kindly identifying the specimens of barnacles. Flavya Mendes de Almeida provided information on the specimens collected by RioZoo. We also thank César Drehmer, Oliver Boisseau and an anonymous referee for their inputs to the manuscript.

\section{References}

Campagna, C. and Lewis, M. (1992) Growth and distribution of a southern elephant seal colony. Marine Mammal Science 8: 387-396.

Castello, H.P. (1984) Registros del elefante marino, Mirounga leonina (Carnivora, Phocidae) en las costas del Atlántico Sur Occidental, fuera del area de cria. Revista del Museo Argentino de Ciencias Naturales, Zoologia, 24(13): 235-243.

Castello, H.P. and Pinedo, M.C. (1977) Os visitantes ocasionais do nosso litoral. Natureza em Revista, Porto Alegre, 3: 40-46

Drehmer, C.J., Ferigolo, J. and Borsato, E.S. (1998) Ocorrência de Mirounga leonina Linnaeus (Pinnipedia, Phocidae) no extremo-sul do Brasil: agressão e patologias. Revista Brasileira de Zoologia 15(4): 1061-1068
King, J.E. (1983) Seals of the World. British Museum (Natural History) and Cornell University Press, 240p.

Lewis, M., Campagna, C. and Quintana, F. (1996) Site fidelity and dispersion of southern elephant seals from Patagonia. Marine Mammal Science 12: 138-146.

Lodi, L. and Siciliano, S. (1989) A southern elephant seal in Brazil. Marine Mammal Science 5: 313.

Pinedo, M.C. (1990) Ocorrência de pinípedes na costa brasileira. Garcia de Orta, Série Zoologia, Lisboa, 15(2): 37-48

Pinedo, M.C., Rosas, F.C.W. and Marmontel, M. (1992) Cetáceos e Pinipedes do Brasil. UNEP/FUA, Manaus, Brazil.

Ross, G.J.B. (1969) The southern elephant seal on South African coasts. Annals of Cape Provincial Museum (Natural History) 6: 12.

Sanctis, B., Souza, S.P. and Alvarenga, F.S. (2002) Nova adição à lista de pinípedes do Estado de São Paulo, Brasil: ocorrências do elefante-marinho-do-sul (Mirounga leonina). Pages 75-76 in Libro de Resúmenes, X Reunión de Trabajo de Especialistas en Mamíferos Acuáticos de América del Sur, IV Congreso de la Sociedad Latinoamericana de Especialistas en Mamíferos Acuáticos (SOLAMAC), 14-19 October, Valdivia, Chile.

Serra, S.D., Hubner, A. and Dórea-Reis, L.W. (2000) Registros de mamíferos marinhos no litoral do Estado de Sergipe. Pages 118-119 in Resúmenes, IX Reunión de Trabajo de Especialistas em Mamíferos Acuáticos de América del Sur, III Congreso de la Sociedad Latinoamericana de Mamíferos Acuáticos-SOLAMAC, 30 October - 3 November, Buenos Aires, Argentina.

Silva, K.G., Barbosa Filho, R.C. and Estima, S.C. (2000) Status de conservação dos pinípedes no litoral do Rio Grande do Sul (RS), Brasil, nos anos de 1998 e 1999. Page 124 in IX Reunión de Trabajo de Especialistas em Mamíferos Acuáticos de América del sur, III Congreso de la Sociedad Latinoamericana de Mamíferos Acuáticos-SOLAMAC, 30 October - 3 November, Buenos Aires, Argentina.

Simões-Lopes, P.C., Drehmer, C.J. \& Ott, P.H. (1995) Nota sobre os Otariidae e Phocidae (Mammalia, Carnivora) da costa norte do Rio Grande do Sul e Santa Catarina, Brasil. Biociências, 3(1): 173-181.

Tarr, P.W. (1987) A southern elephant seal Mirounga leonina (Linn.) resident on the Skeleton Coast, S.W.A./Namibia. Madoqua 15: 265-266.

Valentin, J.L. (2001) The Cabo Frio Upwelling System, Brazil. Pages 97-105 in Seeliger, U. and Kjerfve, B. (Eds) Coastal marine ecosystems of Latin America. Springer-Verlag, Berlin. 